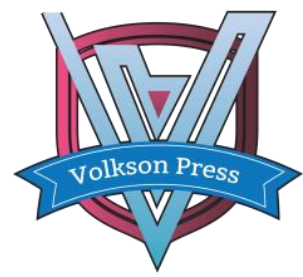

Contents List available at VOLKSON PRESS

Economics \& Management Innovations(EMI)

DOI : http://doi.org/10.26480/icemi.01.2017.250.253

\title{
Key competencies for Industry 4.0
}

\author{
Katarzyna Grzybowska ${ }^{1, *}$ and Anna Łupicka ${ }^{2}$
}

${ }^{1}$ Poznan University of Technology, Strzelecka 11, 60-965 Poznan, Poland

2Poznan University of Economics and Business, Al. Niepodległości 10, 61-875 Poznan, Poland

*katarzyna.grzybowska@put.poznan.pl

This is an open access article distributed under the Creative Commons Attribution License, which permits unrestricted use, distribution, and reproduction in any medium, provided the original work is properly cited.

\section{ARTICLE DETAILS}

\section{Article History:}

Received 02 october 2017

Accepted 06 october 2017

Available online 11 october 2017

\section{Keywords:}

Exchange in the Market, Industry

4.0, development

manufacturing,

competencies,

competencies.

\section{ABSTRACT}

Dynamic development of manufacturing Industry 4.0 is a result of some processes, for example: internationalization, information technology development and also hyper competition. The demand for special skills will drive the shift of job creation within the Industry 4.0 requiring more qualified managers. The high tech manufacturing environment will need both skilled managerial labor and production labor with expertise to work with new materials, machines, and especially information. The demand for special skills will drive the shift of job creation within the Industry 4.0 requiring more qualified managers. The purpose of this article is to find the answer to the following question: what kind of competencies needs contemporary managers to cope with new challenges in Industry 4.0? In this paper the literature review in question has been a point of departure for empirical studies. The presented study contributes to research by providing a starting-point for further research regarding employee competencies for Industry 4.0.

\section{Introduction}

Nowadays changes are becoming faster and more unpredictable. Enterprises have to react very quickly to challenges and opportunities of the business world [1]. Dynamic development of manufacturing Industry 4.0 is a result of some processes, for example: internationalization, information technology development and also hyper competition. The concept of Industry 4.0 describes the increasing digitization of the entire value chain and the resulting interconnection of people, objects and systems through real time data exchange [2]. In spite of enormous progress in industry managers constantly need to face new challenges. The term Industry 4.0 is often referred to as the fourth industrial revolution [3]. Have been proposed on a European level, catchword is "Factories of the Future", "Industrial Internet" in USA and "Internet + " in China [4]. The concept of Industry 4.0 describes the increasing digitization of the entire value chain and the resulting interconnection of people, objects and systems through real time data exchange $[5,6,7]$. Absolutely, Industry 4.0 creates many new opportunities for companies, but at the same time several challenges arising from the ongoing automation and digitization [7]. At the present day, manufacturing is on the brink of the Fourth Industrial Revolution. The digitalization of manufacturing is optimizing the shop floor with integrated technologies and communication technologies [8,9]. With these new integrated systems, it is possible for the factory of the future to be adaptive with respect to the production of individualized products in small batch sizes. Automation will be increasingly important [8]. Consequently, the qualifications and skills of the skilled labor, which are required to fulfil the tasks occurring in a factory of the future, will differ as well $[10,11,12,13,14]$. In Industry 4.0, dynamic business and engineering processes enable last-minute changes to production and deliver the ability to respond flexibly to disruptions $[15,16,17,18,19]$. Production compatible with Industry 4.0 idea is remotely steered, autonomic and robotized structure. In these structures it is necessary to process and analyze large amount of data in real time [20].

The purpose of this article is to find the answer to the following question: what kind of competencies needs contemporary managers to cope with new challenges in Industry 4.0? The article is divided into 3 main parts. The first main part is a theoretical introduction to identification of core managerial competencies. There are presented three essential categories of competencies: technical managerial and social. The next part is introduction to questionnaire research and studies based on questionnaires given to the employed experts in automotive and pharmaceutical sectors. In this part is a comparative analysis of core managerial competencies between two selected sectors of industry.

\section{Identification of key managerial competencies}

According to the literature the authors identified three main categories to classify core managerial competencies. Firstly, technical competencies comprise all job-related knowledge and skills for example media skills, coding skills, knowledge management, and statistical command. Technical skills are abilities an individual acquires through practice and learning. For example, an individual who possesses a particular proficiency or skill set, such as excellent computer coding skills, is a qualifying candidate for a computer or technology company [21]. Secondly, managerial competencies include all skills and abilities for general problem solving and decision making for example: analytical and research skills, conflict and problem solving, creativity. They focus on ability to make business decisions and lead subordinates within a company, include ability, negotiations tactics and response behavior. Thirdly, social competencies include an individual's social values, motivations for example: ability to transfer knowledge, leadership skills, ability to work in a team. Social competence is the foundation upon which expectations for future interaction with others are built, and upon which individuals develop perceptions of their own behavior. Often, the concept of social competence frequently encompasses additional constructs such as social skills, social communication, and interpersonal communication [22].

The study is focused on exploring the managerial competencies of future managers and engineers. Based on existing studies and analyses, a total of eight competencies were identified [23,24,25,26,27,28,29,30,31,32,33,34]. 8 managerial competencies, have been differentiated, which, in the opinion of experts, are of significance in business cooperation. Competences, discussed and selected for analysis, are presented below.

\subsection{Creativity}

Creativity is becoming key focus area for employers looking for the 21st century employee. Creativity is characterised by the ability to perceive the world in new ways, to find hidden patterns, to make connections between seemingly unrelated phenomena, and to generate solutions.

\subsection{Entrepreneurial thinking}


Entrepreneurial thinking skills refer to the ability to identify marketplace opportunities and discover the most appropriate ways and time to capitalize on them. It is more like a state of mind that opens your eyes to new opportunities.

\subsection{Problem solving}

Solving problems involves both analytical and creative skills. Analytical or logical thinking includes skills such as comparing, evaluating and selecting. It provides a logical framework for problem solving. Problem solving is an essential skill in the workplace and personal situations.

\subsection{Conflict solving}

Resolving conflict is a key part of a manager's role. Managing and resolving conflict requires emotional maturity, self -control, and empathy. Resolving conflict in a positive manner is a skill than can be developed and practiced.

\subsection{Decision making}

Decision making is the process of making choices by identifying a decision, gathering information, and assessing alternative resolutions. Decisionmaking is an integral part of modern management. Essentially, Rational or sound decision making is taken as primary function of management. According to the Oxford Advanced Learner's Dictionary the term decision making means - the process of deciding about something important, especially in a group of people or in an organization.

\subsection{Analytical skills}

Analytical skills are the thought processes required to evaluate information effectively. Analytical skills are the ability to visualize, gather information, articulate, analyze, solve complex problems, and make decisions.

\subsection{Research skills}

Research skills can be from need to be able to use reliable sources for continuous learning in changing environments. Being able to provide in depth information and advice on a given topic is an important skill. The most successful people tend to develop research skills early and use them consistently.

\subsection{Efficiency orientation}

An 'efficiency' approach is one that stresses the efficient use of resources as the main determinant od decision and action. Efficiency orientation is inevitable.

\section{Methodology of researches}

In 2017 a questionnaire survey was conducted amongst selected experts in automotive and pharmaceutical industries. These experts are high qualified managers employed in transnational companies. Respondents were asked to indicate of selected competencies. There were 10 experts in each industry sector, who filled in questionnaire.

Two industry branches, the Automotive and Pharmaceutical sectors, were selected for the purpose of study. Their choice was motivated primarily by the specific characteristics of these industries. Both the automotive and pharmaceutical sectors rely on novel technologies, and product and process innovations. Also, both industries search for and employ qualified personnel. Furthermore, they are oriented toward ongoing improvement of competencies. On the other hand, they also differ in certain fundamental aspects. In the automotive sector, it is the entrepreneurship that determines its global reach, whereas in the pharmaceutical industry it is related by social and demographic changes. It is also important to note that despite an increase in efficiency in the pharmaceutical industry, it is still lower than in automotive enterprises.

\subsection{Study results for the automotive sector}

The automotive industry is the highly consolidated sector, with the global overcapacity of about $30 \%$. The market is rather saturated and demand is driven by product replacement. Profit margin on new cars is relatively low, particularly in the low price/high volume segments of the market [35]. The automotive industry is one of the most important worldwide drivers of growth and employment, as well as technological and managerial innovation $[36,37]$.

The automotive industry is a highly competitive market with a widespread use of new technologies and innovations, and a high level of employment. It is not only the fastest growing sector, but also one of the largest employers in the Polish industry, directly responsible for $65 \%$ of all jobs in industrial enterprises. Between 120 and 150 thousand people work at factories producing cars, car parts and subassemblies.

Replies submitted by respondents from the automotive industry are characterized by similar evaluations of selected competencies (Table 1). This applies in particular to competencies related to entrepreneurial thinking, analytical skills and time management abilities. The greatest diversity was noted in the assessment of research skills. The finding is likely to be related to the fact that the value of such competencies for managerial staff in the industrial sector is underestimated.

Table 1. Assessment of competencies in the automotive sector

\begin{tabular}{|c|l|c|c|}
\hline & $\begin{array}{c}\text { Managerial } \\
\text { competencies }\end{array}$ & Arithmetic mean & Standard deviation \\
\hline 1 & Creativity & 3.71 & 0.92 \\
\hline 2 & $\begin{array}{l}\text { Entrepreneurial } \\
\text { thinking }\end{array}$ & 4.57 & 0.53 \\
\hline 3 & Problem solving & 4.25 & 0.71 \\
\hline 4 & Conflict solving & 4.25 & 0.71 \\
\hline 5 & Decision making & 4.57 & 0.92 \\
\hline 6 & Analytical skills & 4.13 & 0.35 \\
\hline 7 & Research skills & 2.38 & 1.51 \\
\hline 8 & Efficiency orientation & 4.50 & 0.53 \\
\hline
\end{tabular}

\subsection{Study results for the pharmaceutical sector}

Pharmaceutical industry is one of the most rapidly growing industrial sectors both in Poland and across the world. It is characterized by a growing degree of automation, robotization and computerization. Polish manufacturers are increasingly oriented towards the markets in advanced drugs. The growth of the industry is chiefly determined by social and economic factors including ageing of the societies, increasing wealth, good economic climate and, last but not least, decisions made by officials. The latter factor grows in importance depending on the price of the drug. In the European Union countries, about $83 \%$ of the price of drugs is paid by institutions responsible for public health.

The pharmaceutical industry ranks among the most stable economic sectors. A growth in society's wealth is accompanied by an increasing demand for pharmaceutical products. As the value of the pharmaceutical market experiences stable growth, pharmaceutical companies need highly qualified personnel.

Replies submitted by experts from the pharmaceutical industry are similar with regard to the decision-making skill (Table 2). All respondents from the sector consider it to be very important for Industry 4.0 workers Similarly to the automotive industry, the greatest variation was observed in the assessment of research skills.

Table 2. Assessment of competencies in the pharmaceutical sector

\begin{tabular}{|c|l|c|c|}
\hline & $\begin{array}{c}\text { Managerial } \\
\text { competencies }\end{array}$ & Arithmetic mean & Standard deviation \\
\hline 1 & Creativity & 2.57 & 0.54 \\
\hline 2 & $\begin{array}{l}\text { Entrepreneurial } \\
\text { thinking }\end{array}$ & 3.57 & 0.79 \\
\hline 3 & Problem solving & 4.86 & 0.38 \\
\hline 4 & Conflict solving & 4.71 & 0.49 \\
\hline 5 & Decision making & 5.00 & 0.00 \\
\hline 6 & Analytical skills & 4.14 & 0.90 \\
\hline 7 & Research skills & 2.29 & 1.38 \\
\hline 8 & Efficiency orientation & 4.43 & 0.53 \\
\hline
\end{tabular}

\subsection{Comparative analysis}

Knowledge becomes a key determinant of the development potential of enterprises [38]. Employees with entrepreneurial thinking skills stand out because they tend to think creatively and take ownership of their jobs as 
well as performance. This is recognized by experts from the automotive sector. Experts (practitioners) attach a very high value to competencies related to decision-making (Fig. 1). Such thinking probably arises from the view that the ability to make optimal and effective decisions is the only way to increase efficiency and win a strategic advantage.

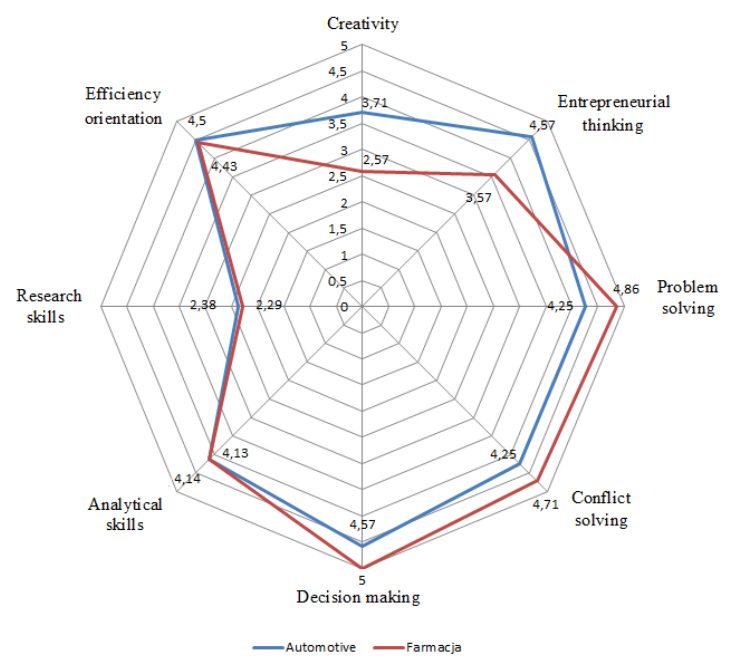

Fig. 1. Comparison of managerial competencies

Even in well-operating enterprises conflict is a natural phenomenon. Conflict usually arises in situations where two or more agents pursue contradictory or discordant goals. It is to be assumed that this is why the conflict resolution skill was given a high value by respondents from the pharmaceutical sector and only slightly lower by respondents from the automotive industry.

Interestingly, the competencies related to research skills were not valued very highly. Research competencies and skills are essential for the effective conduct and understanding of research and ultimately for evidence-based decision-making, whether in business, government or civil society. The development of research competencies is particularly relevant for junior employees whose career is increasingly dependent on their research output. The low assessment may be a result of the specific features of Poland's economy which, unfortunately, lacks in innovation, and therefore is not oriented toward research and the development of research skills.

\section{Conclusions}

The development of new technologies triggers improvements in the quality of life of people and the welfare of whole societies. It is also the main driving force behind the contemporary global economy. Industry 4.0 requires basic research, new solutions implemented in the economy, monitoring of practical effects of such implementations and identification of the potential for new implementations. For those to be possible, employee support and improvement of their competencies are necessary.

\section{Acknowledgement}

Support for this research has been provided by the Faculty of Engineering Management 503217/11/140/DSPB/4150.

\section{References}

[1] Saniuk A., Saniuk S., Caganova D. et al., Control of strategy realization in metallurgical production, 23rd International Conference on Metallurgy and Materials Location: Brno, CZECH REPUBLIC, pp. 1876-1881, (2014)

[2] Dorst W., Glohr C., Hahn T., Knafla F., et al., Umsetzung strategie Industrie 4.0, Ergebnisbericht der Platform Industrie 4.0 (2015)

[3] Kagermann H., Wahlster W., Helbig J., Hellinger A., Stumpf V., Kobsda C., Umsetzungsempfehlungen für das Zukunftsprojekt Industrie 4.0 Abschlussbericht des Arbeitskreises Industrie 4.0. Berlin; (2013)

[4] Mrugalska B., Wyrwicka M.K., Towards Lean Production in Industry 4.0, Procedia Engineering, vol. 182, pp. 466-473, (2017)

[5] Spath D., Ganschar O., Gerlach S., Hämmerle M., Krause T., Schlund S., Produktionsarbeit der Zukunft - Industrie 4.0. Stuttgart: Fraunhofer Verlag; (2013)
[6] Dorst W., Glohr C., Hahn T., Knafla F., Loewen U., Rosen R., et al, Umsetzungsstrategie Industrie 4.0 - Ergebnisbericht der Plattform Industrie 4.0; (2015)

[7] Hecklau F., Galeitzke M., Flachs S., Kohl H., Holistic approach for human resource management in Industry 4.0, Procedia CIRPm Vol. 54,pp. 1-6, DOI: 10.1016/j.procir.2016.05.102, (2016)

[8] Gehrke L., Kühn A.T., Rule D., Moore P., Bellmann Ch., Siemes S., Dawood D., Singh L., Kulik J., Standley M., Industry 4.0 - A Discussion of Qualifications and Skills in the Factory of the Future: A German and American Perspective, Düsseldorf, Germany, (2015)

[9] Kowalski A., Kogut M., Building a database system for management of rail loading processes support. Jedlička $\mathrm{P}$, Marešová $\mathrm{P}$, Soukal I. (eds.), Hradec Economic Days 2017 University of Hradec Králové, pp. 389-399, (2017)

[10] Kowalski A. Juszczyński M., Achieving desired cycle times by modelling production systems, Saeed K. et al. (eds.), Computer information systems and industrial management, CISIM 2013, Springer, pp. 476-486. DOI: $10.1007 / 978-3-642-40925-7 \_44,(2013)$

[11] Gajdzik B., Grzybowska K., Qualifications versus useful knowledge in metallurgical enterprise, METALURGIJA, 53(1), pp. 119-122, DOI: 669.013.003:65.01:658.5:658=111, (2014)

[12] Strategy \& formerly PricewaterhouseCoopers AG, Industry 4.0: Chancen und Herausforderungen der Vierten Industryllen Revolution (2014)

[13] Hirsch-Kreinsen, H., Wandel von Produktionsarbeit - "Industry 4.0", Soziologisches Arbeitspapier, 38 (2014)

[14] Kłosowski G., Gola A., Świć A., Application of Fuzzy Logic in Assigning Workers to Production Tasks, Omatu S., Selamat A., Bocewicz G., et al. (eds.), Distributed Computing and Artificial Intelligence, 13th International Conference, Springer Series: Advances in Intelligent Systems and Computing, Vol. 474, pp. 505-513, (2016)

[15] Jasiulewicz-Kaczmarek M., Saniuk A., Nowicki T., The maintenance management in the macro-ergonomics context, Richard H.M. Goossens (eds.) Advances in Social \& Occupational Ergonomics Proceedings of the AHFE2016, Florida, USA Series: Advances in Intelligent Systems and Computing, Vol. 487 pp. 35-46 DOI: 10.1007/978-3-319-41688-5 (2016)

[16] Burduk A., The role of artificial neural network models in ensuring the stability of systems, 10th International Conference on Soft Computing Models in Industrial and Environmental Applications, Advances in Intelligent Systems and Computing, Springer, pp. 427-437 (2015)

[17] Kiedrowicz M., Nowicki T., Waszkowski R., Wesolowski Z., Worwa K., Method for assessing software reliability of the document management system using the RFID technology, 20th International Conference on Circuits, Systems, Communications and Computers, vol. 76, N. Mastorakis, V. Mladenov, and A. Bulucea, Eds., (2016)

[18] Waszkowski R., Kiedrowicz M., Nowicki T., Wesolowski Z., Worwa K., Business processes in the RFID-equipped restricted access administrative office, 20th International Conference on Circuits, Systems, Communications and Computers, vol. 76, N. Mastorakis, V. Mladenov, and A. Bulucea, Eds. (2016)

[19] Mazur A., Stachowiak A., Gołaś H., Research on the level of organizational maturity in the context of sustainable resources management, Proceedings of 20163 rd International Conference on Social Science (ICSS 2016), vol. 1, DEStech Publications, Inc. Lancaster, USA ISBN: 978-1-60595-410-3, (2016)

[20] Zwolińska B. Algorithm of autonomic shaping of workflow. The First International Conference on Intelligent Systems in Production Engineering and Maintenance ISPEM 2017, Wroclaw University of Science and Technology, Poland, 2017

[21] Technical Job Skills on http://www.investopedia.com skill.html

http://www.businessdictionary.com/definition/managerial-

[23] Relich M., Identifying relationships between eco-innovation and product success. Technology Management for Sustainable Production and Logistics, pp. 173-192, Springer Berlin Heidelberg (2015) 
[24] Joerres J., McAuliffe J., et al. The Future of Jobs - Employment, Skills and Workforce Strategy for the Fourth Industrial Revolution (2016)

[25] Ten Hompel M., Anderl R., Gausemeier J., Meinel C., et al. Kompetenzentwicklungsstudie Industrie 4.0 - ErsteErgebnisse und Schlussfolgerungen. München (2016)

[26] Davies A., Fidler D., Gorbis M., Future Work Skills 2020. Palo Alto (CA) (2011)

[27] Bauer H., Baur C., Camplone G., George K., et al. Industry 4.0 - How to navigate digitization of the manufacturing sector (2015)

[28] Kujawińska A., Vogt K., Hamrol A., The role of human motivation in quality inspection of production processes, Advances in Intelligent Systems and Computing, Volume 490, pp. 569-579 (2016)

[29] Gehrke L., Kühn A.T., Rule D., et al. A Discussion of Qualifications and Skills in the Factory of the Future: A German and American Perspective. Düsseldorf (2015)

[30] Störmer E., Patscha C., Prendergast J., Daheim C., Rhisiart M., Glover P., Beck H., The Future of Work: Jobs and skills in 2030 (2014)

[31] Pompa C. Jobs for the Future. London (2015)
[32] Morgan J., The Future of Work - Attract New Talent, Build Better Leaders, and Create a Competitive Organization. Hoboken (NJ): Wiley (2014)

[33] Sitek, P., Wikarek, J.:A Hybrid Programming Framework for Modeling and Solving Constraint Satisfaction and Optimization Problems,_Scientific Programming vol. 2016, Article ID 5102616, DOI: $10.1155 / 2016 / 5102616(2016)$

[34] Grzybowska K., Gajdzik B., SECI model and facilitation on change management in metallurgical enterprise, METALURGIJA, 52(2), pp. 275278, DOI: 65.01:669.013.003:658.5:658.8=111, (2013)

[35] Golińska P., Kawa A., Remanufacturing in automotive industry: Challenges and limitations, Journal of Industrial Engineering and Management, 3, pp. 453-466, (2011)

[36] Relich M. A declarative approach to new product development in the automotive industry. Environmental Issues in Automotive Industry, pp. 23-45, Springer Berlin Heidelberg (2014)

[37] Pawlewski P., Multimodal Approach to Modeling of Manufacturing Processes, Procedia CIRP Vol. 17, pp. 716-720, (2014)

[38] Grzybowska K., Łupicka A., Knowledge Acquisition in Complex Systems, Proceedings of the 2016 International Conference on Economics and Management Innovations, part of Advances in Computer Science Research vol. 57, ISSN 2352-538X., Yue X.-G., Duarte N.J.R. (eds.), pp. 262 266, DOI: 10.2991/icemi-16.2016.5 (2016) 